Jurnal Independent Vol 5 No. 1

\title{
KEKUATAN PEMBUKTIAN AKTA DIBAWAH TANGAN
}

\author{
Oleh \\ Bambang Eko Muljono \\ Dosen Fakultas Hukum Universitas Islam Lamongan
}

\begin{abstract}
ABSTRAK
Akta adalah sebuah surat yang diberi tanda tangan didalamnya memuat peristiwa yang menjadi dasar dari suatu hak atau perikatan yang sengaja dibuat untuk pembuktian. Akta merupakan syarat formil untuk adanya suatu perbuatan hukum. Akta dibawah tangan adalah suatu akta yang dibuat oleh para pihak tanpa bantuan pejabat yang berwenang dengan tujuan untuk dipergunakan sebagai alat bukti. Akta dibawah tangan mempunyai nilai sebagai permulaan bukti tertulis dan Akta dibawah tangan memiliki kekuatan pembuktian sempurna apabila isi dan tanda tangannya diakui oleh para pihak. Berdasarkan latar belakang masalah tersebut diatas penulis mengutamakan sebuah permasalahan yaitu Bagaimana pengaturan pembuatan akta dibawah tangan dan Bagaimana pembuktian akta dibawah tangan ketika diingkari kebenarannya. Dalam penelitian yang dilakukan oleh penulis mempuyai beberapa tujuan yakni : untuk mengetahui bagaimana pengaturan pembuatan akta dibawah tangan dan untuk mengetahui bagaimana pembuktian akta dibawah tangan ketika diingkari kebenarannya. Tipe penelitian hukum yang digunakan oleh penulis adalah yuridis normatif ( Hukum Normatif ) sedangkan pendekatan masalah yang digunakan dalam penelitian ini adalah pendekatan perundang-undang (statue approach) dalam pendekatan perundangundangan yang perlu dipahami adalah hierarki dan asas-asas dalam perundang-undangan. Bahan hukum yang digunakan dalam hal ini adalah bahan hukum primer, sekunder dan bahan hukum tersier. Dalam penelitian ini penulis menggunakan prosedur pengumpulan bahan hukum studi dokumen atau bahan pustaka dan dalam pengolahan dan analisa bahan hukum penulis menganalisis secara deskriptif. Berdasarkan uraian dalam pembahasan dari bab ke bab maka dapat ditarik kesimpulan bahwa pengaturan pembuatan akta dibawah tangan belum diatur didalam undang-undang sehingga pembuatannya bebas dan sesuai keinginan para pihak dan ketika akta dibawah tangan diingkari kebenarannya maka dalam hal ini pihak yang merasa diingkari harus membuktikan kebenaran atau keaslian akta dibawah tangan tersebut. Selama pihak yang diingkari bisa membuktikan kebenaran akta dibawah tangan tersebut maka akta dibawah tangan tersebut memiliki kekuatan pembuktian yang sempurna.
\end{abstract}

Kata Kunci : Pembuktian, Akta Dibawah Tangan.

\section{A. PENDAHULUAN}

\section{Latar Belakang Masalah}

Membuktikan berarti memberi dasardasar yang cukup kepada hakim yang memeriksa perkara yang bersangkutan guna memberi kepastian tentang kebenaran peristiwa yang diajukan. ${ }^{1}$ Dalam hukum acara perdata alat bukti tertulis atau surat merupakan alat bukti yang utama karena

\footnotetext{
${ }^{1}$ Sudikno Mertokusumo. Hukum acara perdata indonesia. Universitas Atma Jaya Yogyakarta. Yogyakarta. 2010. h.187
}

surat dibuat untuk membuktikan suatu keadaan atau peristiwa yang telah terjadi. Dalam hukum acara perdata terdapat macam-macam alat bukti surat yakni:

1. Surat biasa adalah surat yang ditulis tidak digunakan untuk menjadi alat bukti.

2. Akta. Dalam pasal 1869 BW dijelaskan bahwa: " sebuah surat yang harus diberi tanda tangan yang didalamnya memuat peristiwa-peristiwa yang menjadi dasar dari suatu hak atau perikatan." 
Sedangkan Akta sendiri dibagi menjadi dua yakni akta otentik dan akta dibawah tangan. Sebagaimana dalam pasal 1868 BW akta otentik adalah "suatu akta yang didalam bentuk yang ditentukan oleh undang-undang dibuat oleh atau dihadapan pegawai-pegawai umum yang berkuasa untuk itu ditempat dimana akta dibuatnya". Akta otentik mempunyai kekuatan pembuktian lahir, formal dan material. Sedangkan akta dibawah tangan adalah suatu akta yang dibuat oleh para pihak tanpa bantuan pejabat umum dengan tujuan untuk dipergunakan sebagai alat bukti. $^{2}$ Akta dibawah tangan yang dibuat tidak dihadapan notaris biasanya akta ini dibuat karena para pihak tidak mau repot dan sudah saling memiliki kepercayaan satu sama lain dan menganggap hal tersebut sudah biasa terjadi dikalangan masyarakat desa. Kekuatan pembuktian akta dibawah tangan mempunyai kekuatan pembuktian yang sempurna apabila isi dan tanda tangan diakui oleh para pihak, apabila isi dan tanda tangan tidak diakui maka para pihak yang mengajukan bukti harus menambah bukti dengan bukti lain misalnya saksi. Semakin banyaknya kasus tidak diakuinya kebenaran akta dibawah tangan oleh pihak-pihak yang menandatangani, dan sebagaimana diuraikan diatas.

\section{Tujuan penelitian}

Dalam penelitian yang dilakukan penulis mempuyai beberapa tujuan yakni :

1. Untuk mengetahui bagaimana pengaturan pembuatan akta dibawah tangan.

2. Untuk mengetahui bagaimana pembuktian akta di bawah tangan ketika di ingkari kebenarannya.

\section{B. METODE PENELITIAN}

\footnotetext{
${ }^{2}$ Hari Sasangka. Hukum Pembuktian dalam Perkara Perdata. Mandar maju. Bandung. 2005. h. 56
}

Penelitian merupakan sarana yang dipergunakan oleh manusia untuk memperkuat, membina serta mengembangkan ilmu pengetahuan. ${ }^{3}$ Besarnya manfaat dan kegunaan penelitian, sehingga sangat sulit disangkal, karena dengan penelitian itulah manusia mencari kebenaran yang ditentukan oleh pribadi manusia, lingkaran sosial dan lingkungan alam. jelas sekali betapa luasnya ruang lingkup ilmu pengetahuan, dimana penelitian merupakan suatu sarana untuk mengembangkannya. Penelitian tidak akan mungkin dipisahkan dari ilmu pengetahuan, dan sebaliknya.

Tipe penelitian yang dilakukan dalam penelitian ini adalah dilakukan secara normatif mengenai kekuatan pembuktian akta dibawah tangan.

Pendekatan Masalah Didalam
penelitian hukum terdapat beberapa pendekatan, dengan pendekatan tersebut peneliti akan mendapat informasi dari berbagai aspek mengenai isu yang sedang dicoba untuk mencari jawabannya. Oleh karena itu tipe penelitian yang digunakan adalah pendekatan perundang-undangan (statue approach) dalam pendekatan perundang-undangan peneliti perlu memahami hierarki, dan asas-asas dalam perundang-undangan. Selain itu juga digunakan pendekatan konsep (conseptual). Pendekatan ini digunakan dalam rangka untuk melihat konsepkonsep mengenai kekuatan pembuktian akta dibawah tangan. Dari pengertian tersebut perundang undangan adalah pendekatan dengan menggunakan legislasi dan regulasi. ${ }^{4}$

Bahan Hukum yang digunakan dalam penelitian ini digunakan data sekunder sebagai penyalur kelengkapan data. Data sekunder merupakan metode pengumpulan

\footnotetext{
${ }^{3}$ Soerjono Soekanto. Pengantar penelitian hukum. Universitas Indonesia (UI-Press). Jakarta. 1986.h.3

${ }^{4}$ Peter Mahmud Marzuki.Penelitian hukum.

Penerbit kencana prenadamedia Grup. Jakarta.

2015.h.133
} 
data yang dilakukan secara tidak langsung dengan penelitian kepustakaan, untuk mendapatkan landasan teoritis dan beberapa pendapat maupun tulisan para ahli dan juga untuk memperoleh informasi baik dalam bentuk ketentuan formal maupun data melalui naskah resmi yang ada. Data sekunder dalam penelitian ini dikelompokkan menjadi 3 (tiga), yaitu :

1. Bahan Hukum Primer, yaitu bahan yang mengikat, terdiri dari :
a. Kitab Undang-undang Hukum Perdata
b. HIR (Herziene Inlandsch Reglemen).
c. Rbg (Reglement voor de Buitengewesten).
d. Rv (Reglemen op de Burgerlijk Rechtvordering).

2. Bahan Hukum Sekunder, yaitu bahan yang memberi penjelasan bagi bahan primer, terdiri dari :
a. Buku-buku atau hasil penelitian yang membahas tentang hukum pembuktian dalam perkara perdata
b. Dokumen-dokumen yang membahas tentang pembuktian dalam perkara perdata.

3. Bahan Hukum Tersier, yaitu bahan Hukum yang memberikan petunjuk dan penjelasan terhadap bahan hukum primer dan sekunder, terdiri dari Kamus Hukum, Kamus Besar Bahasa Indonesia.

\section{Prosedur Pengumpulan Bahan Hukum.}

Sebagaimana telah diketahui, maka didalam penelitian lazimnya dikenal paling sedikit tiga jenis alat pengumpulan data, yaitu studi dokumen atau bahan pustaka, pengamatan atau observasi, dan wawancara atau interview. Ketiga jenis alat pengumpulan data tersebut dapat dipergunakan masing-masing, maupun secara bergabung untuk mendapatkan hasil yang semaksimal mungkin. Hal ini disebabkan, oleh karena masing-masing jenis alat pengumpul data tersebut, mempunyai kelemahan dan kelebihannya. ${ }^{5}$

Dalam penelitian ini penulis menggunakan prosedur studi dokumen atau bahan pustaka. Studi dokumen merupakan suatu prosedur pengumpulan data yang dilakukan melalui data tertulis seperti undang-undang, buku-buku hasil penelitian dari para ahli, majalah, dan lainlain.

\section{Pengolahan dan Analisa Bahan Hukum.}

Pada dasarnya pengolahan, analisa, dan konstruksi data dapat dilakukan secara kwalitatif dan / atau secara kwantitatif. Kadang-kadang penyajian hasil-hasil penelitian (sebagai hasil pengolahan data) disatukan dengan analisa data. Tidak jarang pula kedua hal itu dipisahkan satu dengan lainnya. maka penyajian hasil penelitian sifatnya adalah semata-mata deskriptif. Dalam hal ini tidak ada suatu kemutlakan untuk menekankan pada salah satu cara. Oleh karena itu pengolahan dan analisa bahan hukum dalam penulisan ini diperoleh dari penelitian yang akan dianalisis secara Deskriptif, yaitu menjelaskan atau menggambarkan kenyataan-kenyataan yang terjadi pada obyek penelitian secara tepat dan jelas untuk memperoleh kejelasan tentang masalah yang timbul. ${ }^{6}$

\section{HASIL PENELITIAN DAN PEMBAHASAN \\ Pengaturan Pembuatan Akta Dibawah Tangan}

Akta dibawah tangan diatur dalam pasal 1874 kitab undang-undang hukum perdata yang sebagaimana berikut:"sebagai tulisan-tulisan dibawah tangan dianggap akta-akta yang ditandatangani dibawah tangan, surat-surat, register-register, suratsurat urusan rumah tangga dan lain-lain tulisan yang dibuat tanpa perantaraan

\footnotetext{
${ }^{5}$ Soerjono Soekanto.Op Cit.h. 66

${ }^{6}$ Ibid.h.68
} 
seorang pegawai umum. Dengan penandatanganan sepucuk tulisan dibawah tangan dipersamakan suatu cap jempol, dibubuhi dengan suatu pernyataan yang bertanggal dari seorang notaris atau seorang pegawai lain yang ditunjuk oleh undang-undang darimana ternyata bahwa ia mengenal si pembubuh cap jempol, atau bahwa orang ini telah diperkenalkan kepadanya bahwa isinya akta telah dijelaskan kepada orang itu dan bahwa setelah itu cap jempol tersebut dibubuhkan dihadapan pegawai tadi. Pegawai ini harus membukukan tulisan tersebut. Dengan undang-undang dapat diadakan aturanaturan lebih lanjut tentang pernyataan dan pembuatan tersebut". Dalam pasal 286 Stbl 1927 No. 227 (Rbg) sebagaimana berikut: "akta-akta dibawah tangan adalah akta-akta yang ditandatangani dibawah tangan, surat-surat, daftar-daftar, suratsurat mengenai rumah tangga dan suratsurat lain yang dibuat tanpa campur tangan pejabat pemerintah". Dalam pasal diatas akta dibawah tangan akta dibawah tangan haruslah dibuat dan ditandatangani dibawah tangan tidak dibuat dan ditandatangani dihadapan pejabat yang berwenang tetapi dibuat sendiri oleh para pihak . pembuatan akta dibawah tangan biasanya diikuti setelah terpenuhinya syarat sah perjanjian yang terdapat dalam kitab undang-undang hukum perdata pasal 1320 sebagai berikut : untuk sah nya suatu perjanjian diperlukan empat syarat yakni:

1. Sepakat mereka yang mengikat dirinya

2. Kecakapan untuk membuat suatu perikatan

3. Suatu hal tertentu

4. Suatu sebab yang halal.

Kekuatan Pembuktian Akta Dibawah Tangan Serta Akibat Hukum Dari Adanya Pengingkaran Kebenaran Akta Dibawah Tangan

\section{A. Pembuktian akta dibawah tangan}

Hukum pembuktian akta dibawah tangan merupakan bagian yang sangat kompleksdalam proses litigasi keadaan kompleksitasnya makin rumit karena pembuktian berkaitan dengan kemampuan merekonstruksi kejadian atau peristiwa masa lalu (past event) sebagai suatu kebenaran (truth). Yang harus dibuktikan dalam akta dibawah tangan adalah adanya perjanjian akta dibawah tangan serta kebenaran tanda tangan dari para pihak yang ada dalam perjanjian akta dibawah tangan. Dalam penilaian pembuktian terdapat tiga teori yakni teori pembuktian bebas, teori pembuktian negatif, teori pembuktian positif. Beban pembuktian diatur dalam pasal 163 stbl 1941 No. 44 HIR, pasal 283 stbl 1927 No. 227 Rbg, dan pasal 1865 Kitab Undang-undang Hukum Perdata. Yakni siapa yang mengakui mempunyai hak maka orang yang mengakui mempunyai hak tersebut harus membuktikan haknya. Alat-alat bukti dapat bersifat oiral, documentary atau material. Alat bukti yang bersifat oral merupakan kata-kata yang diucapkan oleh seseorang dipersidangan, kesaksian tentang suatu peristiwa, sedangkan alat bukti yang bersifat documentary adalah surat. Dan alat bukti yang bersifat material adalah barang fisik lainnya selain dokumen. Macam macam alat bukti diatur dalam pasal 164 stbl 1941 No. 44 HIR, pasal 284 stbl 1927 No. 227 Rbg, pasal 1866 Kitab undang undang hukum perdata. Daya kekuatan pembuktian akta dibawah tangan yakni kekuatan pembuktian formil dan kekuatan pembuktuian materiil. Yang termasuk daya kekuatan pembuktian formil adalah kebenaran identitas penandatanganan, menyangkut kebenaran identitas orang yang memberi keterangan. Sedangkan yang termasuk daya pembuktian materiil adalah isi keterangan yang tercantum didalam akta dibawah tangan. Pembuktian dengan saksi, alat bukti kesaksian diatur dalam pasal 139-152, pasal 158-172 stbl 1941 No. 44 HIR, pasal 165-179 stbl 1927 No. 227 Rbg, pasal 1895 dan pasal 19021912 kitab undang-undang hukum perdata. Dalam hal ini yang harus dibuktikandalam pembuktian kekuatan akta dibawah tangan yakni saksi yang benar-benar mengetahui 
bahwa pada waktu itu penggugat dan tergugat mengadakan perjanjian jual beli, bahwa isi atau pernyataan yang ada didalam akta dibawah tangan tersebut memang benar adanya. Alat bukti persangkaan diaturdalam pasal 164 stbl 1941 No. 44 HIR, pasal 284 stbl 1927 No. 227 Rbg, pasal 1866 kitab undang-undang hukum perdata. Akat bukti persangkaan merupakan alat bukti yang bersifattidak langsung. Dalam hal ini pengingkaran akta dibawah tangan pada saat pembuatan akta dibawah tangan ditahun 1994 para pihak mengakui kebenarannya namun pada saat tahun 2016 tidak diakui kebenarannya oleh pihak penjual . dalam hal ini dapat menimbulkan persangkaan hakim, mengapa tidak diingkari sejak dahulu baru dibuatnya akta dibawah tangan dan mengapa sudah bertahun-tahun lamanya baru diingkari kebenaran akta dibawah tangan tersebut. Alat bukti pengakuan diatur dalam pasal 174-176 stbl 1941 No. 44HIR. Pasal 311-313 stbl 1927 No. 227 Rbg dan pasal 1923, pasal 1928 kitab undang-undang hukum perdata. Pengakuan dapat dibenarkan dimuka hakim dipersidangan atau diluar persidangan. Alat bukti sumpah diatur dalam pasal 155, pasal 158, pasal 177 stbl 1941 No. 44 HIR, pasal 182-185, pasal 314 stbl 1927 No. 227 Rbg, pasal 1929-1945 kitab undangundang hukum perdata. Macam-macam sumpah: sumpah suppletoir, sumpah penaksiran yang diatur dalam pasal 155 stbl 1941 No. 44 HIR, pasal 182 stbl 1927No. 227 Rbg, pasal 1940 undangundang hukum perdata, sumpah decisoir yang diatur dalam pasal 156 stbl 1941 No. 44 HIR, pasal 183 stbl 1927 No. 227 Rbg, pasal 1930 kitab undang-undang hukum perdata. Pemeriksaan setempat bukanlah termasuk alat bukti, sebagaimana telah diatur dalam pasal 1866 kitab undangundang hukum perdata atau pasal $164 \mathrm{stbl}$ 1941 No. 44 HIR maupun pasal 284 stbl 1927 No. 227 Rbg. Dalam pasal 153 stbl 1941 No. 44 HIR sebagai berikut :

1. jika dipandang perlu atau faedahnya, maka ketua boleh mengangkat satu atau dua komisaris dari dewan itu yang dengan bantuan panitera Pengadilan Negeri akan melihat keadaan tempat atau menjalankan pemeriksaan ditempat itu yang dapat menjadi keterangan bagi hakim.

2. Panitera pengadilan hendaklah membuat proses perbal atau berita acara tentang pekerjaan itu dan hasilnya yang perlu ditandatangani oleh komisariskomisaris dan panitera pengadilan itu.

Dalam hal peristiwa pembuktian kekuatan akta dibawah tangan yang menjadi obyeknya disini adalah tanah. Setelah dilakukan pemeriksaan setempat hakim beserta panitera mengetahui batas-batas, letak obyek dan luas tanah tersebut sama dengan yang ada pada akta dibawah tangan. Pendapat ahli diatur dalam pasal 154 stbl 1941 No. 44 HIR maupun pasal 215-229 stbl 1847 No. 52 jo 1849 No. 63 Rv.

Putusan hakim dalam peristiwa kebenaran akta dibawah tangan yakni :

1. Menyatakan obyek sengketa adalah milik tergugat

2. Menghukum tergugat rekopensi atau penggugat untuk membayar uang paksa (dwangsom) sebesar Rp. 100.000,(seratus ribu rupiah) setiapbulan keterlambatannya penggugat menjalankan isi putusan ini. Jadi dalam hal ini pihak tergugat atau pihak yang memegang akta dibawah tangan menjadi pemilik sah dari obyek yang disengketakan.

Akibat hukum dari adanya pengingkaran kebenaran akta dibawah tangan Jika akta dibawah tangan terbukti kebenarannya maka pihak yang mengingkari kebenaran tersebut dinyatakan oleh hakim tidak berhak atas obyek yang disengketakan.

\section{PENUTUP Kesimpulan}


Dari penjelasan yang dijabarkan oleh penulis tersebut diatas dapat ditarik beberapa kesimpulan, antara lain :

1. Akta dibawah tangan merupakan akta yang dibuat oleh para pihak tanpa bantuan pejabat umum dengan tujuan digunakan sebagai alat bukti. Pengaturan pembuatan akta dibawah tangan belum diatur didalam undangundang sehingga pembuatannya bebas dan sesuai keinginan para pihak.

2. Ketika akta dibawah tangan diingkari kebenarannya maka dalam hal ini pihak yang merasa diingkari harus membuktikan kebenaran atau keaslian akta dibawah tangan tersebut. Selama pihak yang diingkari bisa membuktikan kebenaran akta dibawah tangan tersebut maka akta dibawah tangan tersebut memiliki kekuatan pembuktian yang sempurna.

\section{Saran-saran}

1. Seharusnya pembuatan akta dibawah tangan digunakan untuk perbuatanperbuatan yang hukumnya tidak memberikan dampak atau kerugian yang besar apabila terjadi pengingkaran atas akta tersebut.

2. Dalam hal ini masyarakat lebih baik membuat akta otentik dari pada akta dibawah tangan karena akta otentik sudah diatur didalam undang-undang.

\section{E. DAFTAR PUSTAKA}

\section{Literatur}

Hari Sasangka. Hukum Pembuktian dalam Perkara Perdata, Penerbit Mandar Maju, Bandung, Tahun 2005.
M Yahya Harahap. Hukum Acara Perdata, Penerbit Sinar Grafika, Jakarta, Cetakan ketiga belas, Tahun 2013.

Peter Mahmud Marzuki. Penelitian Hukum, Penerbit Prenandamedia Grup, Jakarta, Tahun 2015.

Soerjono Soekanto. Pengantar Penelitian Hukum, Penerbit Universitas indonesia (UI PRESS), Jakarta, Tahun 2014.

Sudikno mertokusumo. Hukum Acara Perdata Indonesia, Penerbit Universitas Atma Jaya Yogyakarta, Yogyakarta, Tahun 2010.

\section{Perundang-Undangan}

1. Kitab Undang-undang Hukum Perdata.

2. HIR (Herzien Inlandsch Reglement)

3. $\mathrm{Rbg}$ (Reglement voor de Buitengewesten)

\section{Internet}

http://www.jurnalhukum.com//syarat-syaratsahnya-perjanjian

http://www.jurnalhukum.com//teori-teoriyang-digunakan-untuk-menentukanterjadinya-

kesepakatan//wibowoTunardy//22//08//2012 /hukumperikatan

http://www.jurnalhukum.com//perbedaanakta-otentik-dan-surat-dibawahtangan//irma-devita-purnama-sari http://legalakses.blogspot.com/2014/11/peng ertian-dan-perbedaan-akta-otentik-dan-aktadibawah-tangan.html 